\title{
Diary Skizofrenia untuk Meningkatkan Kemampuan Penderita Skizofrenia Berbasis Android
}

\author{
Abdi Pandu Kusuma ${ }^{1}$, Miza Rahmatika Aini ${ }^{2}$ \\ ${ }^{1,2}$ Program Studi Sistem Komputer Fakultas Teknologi Informasi, Program Studi Pendidikan \\ Bahasa Inggris Fakultas Keguruan dan Ilmu Pendidikan \\ Universitas Islam Balitar \\ 1,2 Jl.Mojopahit 4A, Kota Blitar, Jawa Timur, telp. (0342) 813145 \\ e-mail: ${ }^{1}$ pans.uib1blitar@gmail.com, ${ }^{2}$ jumintenlarasati@gmail.com
}

\begin{abstract}
Abstrak
Skizofrenia merupakan penyakit disabilitas yang berfokus pada keterpecahan informasi pada otak. Perlu adanya treatment yang dilakukan untuk menyembuhkan penderita dari hendaya kognitif yang diderita. Melihat fenomena tersebut, peneliti merancang suatu aplikasi yang bernama Diary Skizofrenia Untuk Meningkatkan Kemampuan Penderita Skizofrenia. Aplikasi tersebut berisi pertanyaan bacaan, melihat video, mendengarkan lagu, melengkapi kalimat rumpang, dan menata bangun ruang. Pengukuran yang dilakukan adalah menggunakan skala ScoRs (Schizophrenia cognitive Rating Scale). Pengujian aplikasi dilakukan menggunakan alpha testing dan beta testing. Alpha testing dilakukan dengan pengujian black box dengan tingkat akurasi pengujian sebesar 76,19\%, sedangkan Beta testing dilakukan dengan pengujian terhadap ahli media dan dokter psikiater dengan hasil presentase masingmasing sebesar 45,45 \%. Hasil Penerapan aplikasi yang diterapkan pada penderita Skizofrenia dari Posyanndu Desa Jajar Talun berbanding lurus dengan skala Scors yang diujikan.
\end{abstract}

Kata kunci: skizophrenia, Scizophrenic's Diary, ScoRs, Alpha testing, Beta testing.

\begin{abstract}
Skizophrenia is a disability disease that focuses on the dissage of information on the brain. There needs to be treatment done to cure sufferers of cognitive hendaya suffered. Looking at the phenomenon, researchers designed an app an application called Schizophrenia Diary to Improve the Ability of Schizophrenics. The app contains reading questions, viewing videos, listening to songs, completing sentences, and organizing space builds. Measurement is used using ScoRs (Schizophrenia cognitive Rating Scale). Application testing is done using alpha testing and beta testing. Alpha testing is done with black box testing with a test accuracy rate of 76,19\%, while Beta testing is done by testing media experts and psychiatrists with a percentage result of 45,45\%. The results of the application applied to schizophrenia sufferers from Posyanndu, Jajar Talun Village are directly proportional to the Scors scale tested.
\end{abstract}

Keywords: skizofrenia, Scizophrenic's Diary, ScoRs, Alpha testing, Beta testing.

\section{Pendahuluan}

Skizofrenia merupakan suatu kelainan yang heterogen antara factor genetic dan factor lingkungan yang saling berinteraksi dan berkontribusi resiko perkembangan gangguan ini [1]. Penderita skizofrenia biasanya cenderung tidak mampu menghubungkan pikirn-pikiran yang muncul dalam dirinya yang menyebabkan menghilangnya kemampuan atau kemauan untuk melakukan aktifitas sehari hari-hari dalam pemenuhan kebutuhan dasarnya selain kebutuhan makan dan tidurnya, ketidakmampuan penderita dalam melakukan perawatan diri dapat mengakibatkan klien mengalami defisit perawatan diri [2].

Penderita skizofrenia mengalami gejala yang berupa halusinasi, delusi dan waham atau keyakinan yang salah (false beliefef). Skizofrenia merupakan gangguan kesehatan mental kronis 
yang kompleks yang ditandai dengan serangkaian gejala, termasuk delusi, halusinasi, ucapan atau perilaku yang tidak teratur, dan gangguan kemampuan kognitif. Awal penyakit ini, bersama dengan perjalanan kronisnya, menjadikannya gangguan yang melumpuhkan bagi banyak pasien dan keluarganya. Disabilitas sering kali diakibatkan oleh gejala negatif (ditandai dengan kehilangan atau defisit) dan gejala kognitif, seperti gangguan perhatian, memori kerja, atau fungsi eksekutif. Selain itu, kekambuhan dapat terjadi karena gejala positif, seperti kecurigaan, delusi, dan halusinasi. Perawatan diri merupakan salah satu aspek penting bagi orang dengan skizofrenia. Bagi penderita skizofrenia, perawatan diri merupakan masalah yang sering di hadapi mereka [3].

Ketika Bleuler (1950) menciptakan istilah skizofrenia dia berhati-hati untuk menyarankan bahwa itu merujuk pada sekelompok gangguan yang berbagi satu kualitas umum, fragmentasi pengalaman mental terintegrasi sebelumnya. Dipengaruhi oleh interaksi tatap muka dengan pasien, dan dalamkolaborasi dengan Jung (1936), Bleuler menggunakan konstruksi seperti "Split" untuk menggambarkan hilangnya persatuan atau koherensi antar mentalaktivitas di tiga bidang utama fungsi psikologis: kognisi, emosi dan kemauan [4].

Gejala skizofrenia bisa dikategorikan menjadi kategori 'positif', 'negatif' dan 'kognitif'. Gejala positif terdiri dari perilaku dan pikiran yang biasanya tidak ada, seperti psikosis berulang, yang terdiri dari 'kehilangan kontak dengn realitas' delusi, halusinasi dan bicara tidak teratur dan tingkah laku. Sindrom amotivasi ditandai dengan gejala negatif, yang meliputi penarikan sosial, perataan afektif, anhedonia (ketidakmampuan untuk merasakan kesenangan) dan berkurangnya inisiatif dan energi. Akhirnya, gejala kognitif diekspresikan sebagai rangkaian luas disfungsi kognitif [5]. Gangguan kognitif adalah ciri yang menonjol dan sulit diobati skizofrenia dan berhubungan langsung dengan kecacatan fungsional. Terdapat fakta bahwa etiologi yang mendasari disfungsi kognitif Skizofrenia tidak diketahui, namun data konvergen mendukung perkembangan saraf model di mana faktor genetic memainkan peran penting [6]. Seperti yang dikatakan oleh Carrion et al dalam jurnal yang berjudul "Does childhood trauma influence cognitive functioning in schizophrenia? The association of childhood trauma and cognition in schizophrenia spectrum disorders" karya Merkved et al [7], penderita skizofrenia mengalami disabilitas dalam hal kemampuan kognitifnya. Ketimpangan tersebut merupakan suatu permasalahan inti yang menjadi penyebab adanya gejala pada penderita skizofrenia. Defisit pada kognisinya menyebabkan kemiskinan isi pikir dan cara berpikir atau menginterpretasikan lingkungannya.

Pernyataan Rapoport and Gogtay dalam jurnal Cognitive functioning in adolescents with schizophrenia treated with paliperidone extended-release: 6-Month exploratory analysis from an openlabel, single-arm safety study tersebut [8] menyatakan bahwa skizofrenia merupakan suatu penyakit yang serius. Penyakit tersebut diderita selama sumur hidup. Seseorang yang menderita skizofrenia memiliki kesehatan klinis yang buruk, bahkan seringkali mengalami kegagalan di sekolah. Orang Dengan Skizofrenia (ODS) baik anak-anak maupun dewasa mengalami defisit atau hendaya kognitif yang signifikan yang sangat persisten dan berkesinambungan dalam hidupnya.

Defisit kognitif tersebut berpengaruh, pertama pada kemampuan linguistiknya. Penderita tidak mampu menangkap makna literal atau non literal yang terdapat dalam suatu wacana, baik itu wacana diskusi maupun wacana produk bacaan (literasi). Deamer et al dalam jurnalnya yang berjudul "Non Literal understanding and psychosis : Metaphor comprehension in individuals with a diagnosis of schizophrenia " [9] menyebutkan bahwa "Seperti semua orang, pasien dengan diagnosis Skizofrenia telah terpapar pada bahasa non literal sejak mereka memasuki dunia linguistik, namun mereka dipertimbangkan dalam kemampuan mereka untuk secara akurat menafsirkan ekspresi non literal selama episode akut dan ketika dalam remisi". Hal tersebut pada masa remisi pun, penderita skizofrenia masih sulit mengartikan atau menginterpretasikan ucapan dan membaca wacana sosial yang ada di sekelilingnya. Mereka sulit sekali mengartikan kata-kata yang diucapkan penutur kepada mereka sebagai mitra tutur. Contohnya adalah sebagai berikut 
Salah satu contoh bentuk gangguan berbahasa yang berarti gangguan kognitif pada penderita skizofrenia adalah wacana tuturan maupun tulisan tidak beraturan..

"Akhirnya kami yakin 100\% bahwa perintah Rasul pasti banyak yang menjalankan dan pasti terwujud berdasarkan sabda Rasullulah lewat"

1. Demokrasi manusia Internasional SEHAT JIWA di SWEDIA Newyork/RSA, bahwa kepemimpinan Indonesia-Indonesisich mensfeeld akan muncul th. 2015

Demokrasi manusia sehat jiwa diantaranya

a. Prof.Dr.Dr. I. Magnis Soeseno dari Sekolah Tinggi Ilmu Filsafat Etika Griya R. RARA Jakarta

b. Prof. Dr. Bapang Nasution, SH, MH

c. Tokoh-tokoh Media Cetak + televise yang menolak produk

d. eksekutif, yudikatif, dan legislative NKRI PREMANISME 1965-2014.

Penderita skizofrenia ini mengirim surat yang tidak jelas ditujukan kepada siapa dengan kop surat bertuliskan RASULULLAH

Tulisan ini ditulis oleh penderita skizofrenia hebefrenik. Penderita menulis surat yang dimasukkan ke dalam amplop kemudian diserahkan kepada dokter yang merawatnya di poli RSUD Dr. Sutomo [10].

Dari data tersebut dapat diketahui bahwa penderita skizofrenia mengalami kesalahan berpikir, keyakisnan yang salah bahwa diri mereka adalah seorang Rasul, Utusan atau Messiah. Pada penderita yang pada tahap akut, waham masih terlihat jelas bahwa keyakinannya itu tidak dapat dipatahkan oleh argument lain.

Dari tulisan tersebut juga dapat diketahui bahwa penderita skizofrenia mengalami defisit kognitif dalam bidang linguistic yang berarti banyak penyimpangan berbahasa yang bersifat tidak koheren. Isi pikir yang salah yang dialami oleh penderita skizofrenia merupakan bukti nyata bahwa penderita tersebut mengalami defisit dalam kognisinya.

Kognisi merupakan hal terpenting dalam kehidupan sehari-hari seperti: fungsi pribadi, sosial, dan pekerjaan.Kognisi merupakan suatu kemampuan untuk memperhatikan sesuatu secara selektif dan terfokus, berkonsentrasi selama periode waktu tertentu, mempelajari ketrampilan dan informasi baru, merencanakan sesuatu, menentukan strategi tindakan dan mengeksekusinya, memahami bahasa dan menggunakan ketrampilan verbal untuk berkomunikasi dan mengekspresikan diri, serta menyimpan informasi dan memanipulasinya untuk menyelesaikan masalah yang kompleks merupakan fungsi kognitif [1]. Gangguan kognitif adalah fitur inti dari skizofrenia. Memahami sifat dan arah dari gangguan ini mungkin memiliki implikasi penting untuk pemahaman kita tentang patofisiologi gangguan tersebut [11]. Kognisi merupakan fungsi penting pada otak, yang merupakan penggabungan suatu proses mental untuk mendapatkan pengetahuan dan peduli terhadap lingkungan sekitar sehingga mampu melakukan tindak eksekutif atau pengambilan keputusan. Kognisi berpengaruh terhadap ketrampilan dalam memecahkan suatu masalah, membuat keputusan dan kreativitas [1].

Defisit atau hendaya kognitif membuat penderita skizofrenia mengalami kekosongan pikiran dan kelemahan dalam kreativitas dan pengambilan keputusan. Tugas atau pekerjaan yang kiranya bias dilakukan orang biasa seerti pekerjaan rumah tangga, atau aktivitas ringan seperti olahraga berjalan kaki menjadi suatu beban bagi mereka. Dalam observasi yang dilakukan peneliti di desa Jajar Kabupaten Blitar pada bulan Juli-Agustus 2019 bahkan ada seorang ibu rumah tangga yang tidak bias melakukan aktivitas rumah tangga seperti memasak, menyapu, membersihkan rumah dan merawat anaknya. Adapula penderita skizofrenia yang mempunyai waktu tidur yang sangat panjang yakni mulai pukul 03.00 dini hari sampai jam 13.00. Dalam observasi yang dilakukan mereka bahkan tidak mampu menjawab pertanyaan sederhana seperti apa cita-citamu, bagaimana kamu mengatur keuangan. Bahkan menceritakan kembali video yang dilihat sangat kesulitan bagi mereka.

Melihat fenomena tersebut, peneliti berinisiatif untuk membuat suatu aplikasi untuk mengurangi atau menurunkan hendaya kognitif atau defisit kognitif penderita skizofrenia. Aplikasi tersebut bernama Diary Skizofrenia Untuk Meningkatkan Kemampuan Penderita Skizofrenia. Aplikasi tersebut berupa pertanyaan bacaan, melihat video, mendengarkan lagu, 
melengkapi kalimat rumpang dsan menyusun bangun ruang. Treatment tersebut adalah untuk melatih kemampuan kognisinya pada masa remisi.

Efek sedang dari kinerja positif dapat diperbaiki dari remediasi kognitif untuk penelitian meta analisis [12]. Mengingat signifikansinya kognisi sosial untuk hasil fungsional, intervensi kognitif yang menggabungkan pelatihan kognitif dan social mungkin lebih cocok untuk mencapai pemulihan penyakit secara klinis [14]. Terapi kognitif adalah terapi jangka pendek yang teratur, yang memberikan dasar berpikir pada klien untuk mengekspresikan perasaan negatifnya, memahami masalahnya serta mampu mengatasi perasaan negatifnya dan mampu memecahkan masalah tersebut. Terapi ini juga bertujuan untuk meningkatkan aktivitas, mengurangi perilaku yang tidak diinginkan serta meningkatkan keterampilan sosial [15]

Treatment yang dilakukan merupakan salah satu jenis terapi kognitif Terapi kognitif bagian dari psikoterapi yang dapat diberikan terhadap beberapa jenis gangguan jiwa. Terapi kognitif suatu jenis terapi jangka pendek yang teratur yang memberikan dasar berfikir pada pasien untuk mengerti masalahnya, memiliki kata-kata untuk menyatakan dirinya dan teknikteknik untuk mengatasi keadaan perasaan yang sulit, serta teknik pemecahan masalah [13].

Sebelum diberikan treatment, orang dengan skizofrenia diuji dengan menggunakan aplikasi Schizophrenia Diary untuk membantu hendaya kognitif dan meningkatkan kemampuan berkomunikasi penderita skizofrenia menjadi lebih baik kembali.

\section{Metode Penelitian}

\subsection{Subjek Penelitian}

Jumlah subyek penelitian sebanyak 10 orang dan subyek dipilih berdasarkan kriteria yang ditetapkan yaitu purposive sampling. Subyek penelitian adalah penderita gangguan jiwa ringan hingga sedang dengan diagnosis skizofrenia yang sedang menjalani pemeriksaan rutin di Polindes Jajar Kecamatan Talun Kabupaten Blitar yang memenuhi kriteria dengan nilai PANSS EC $<20$ pada penderita skizofrenia.

\subsection{Instrument Penelitian}

Langkah pertama yakni dengan mengukur Skala PANSS (Positive and Negative Syndrome Scale). Skala PANSS merupakan penilaian gejala negatif dari skizofrenia yang meliputi: afek tumpul, penarikan emosional, kemiskinan rapport, penarikan diri dari hubungan sosial secara pasif, kesulitan dalam pemikiran abstrak dan kurangnya spontanitas dan arus percakapan. Skala. Langkah kedua dilakukan dengan mengukur skala scors yakni suatu instrumen penelitian yang terdiri dari 10 item pertanyaan yang meliputi ranah atensi, memori kerja, kecepatan pemrosesan, pertimbangan dan pemecahan masalah, pembelajaran dan memori verbal, pembelajaran dan memori visual, dan kognisi sosial. Selain itu penderita diberi soal terlebih dahulu berupa lembar observasi untuk mengukur kemampuan kognitifnya.

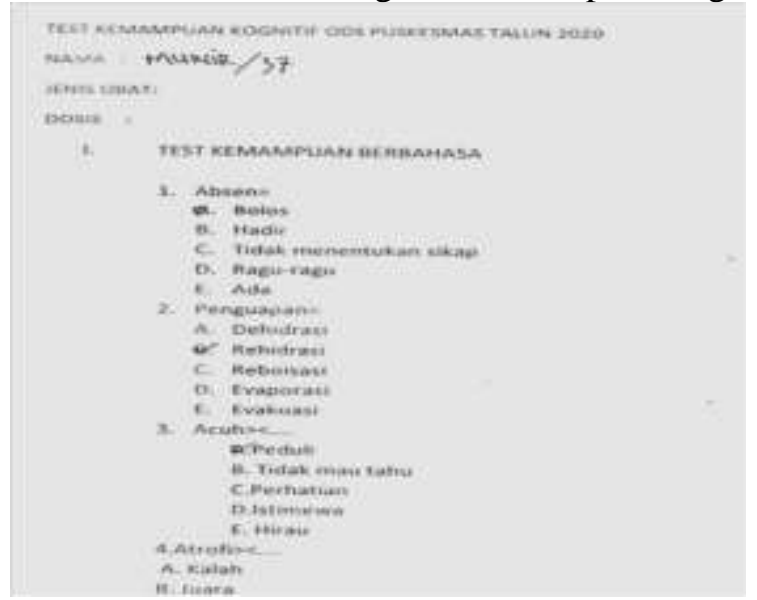

Gambar 1. Lembar Obervasi

Beberapa pertanyaan panduan yang menggambarkan kemampuan fungsi dalam konteks kehidupan sehari-hari ditampilkan seperti gambar 1. 


\subsection{Perancangan Sistem}

Rancangan sistem dapat dilakukan dalam bentuk Data Flow Diagram (DFD) dan Flowchart.

\subsubsection{Data Flow Diagram (DFD)}

Perancangan bentuk DFD dilakukan untuk menampilkan alur sistem penggunaan aplikasi skizofrenia yang dapat ditampilkan pada gambar 2 berikut.

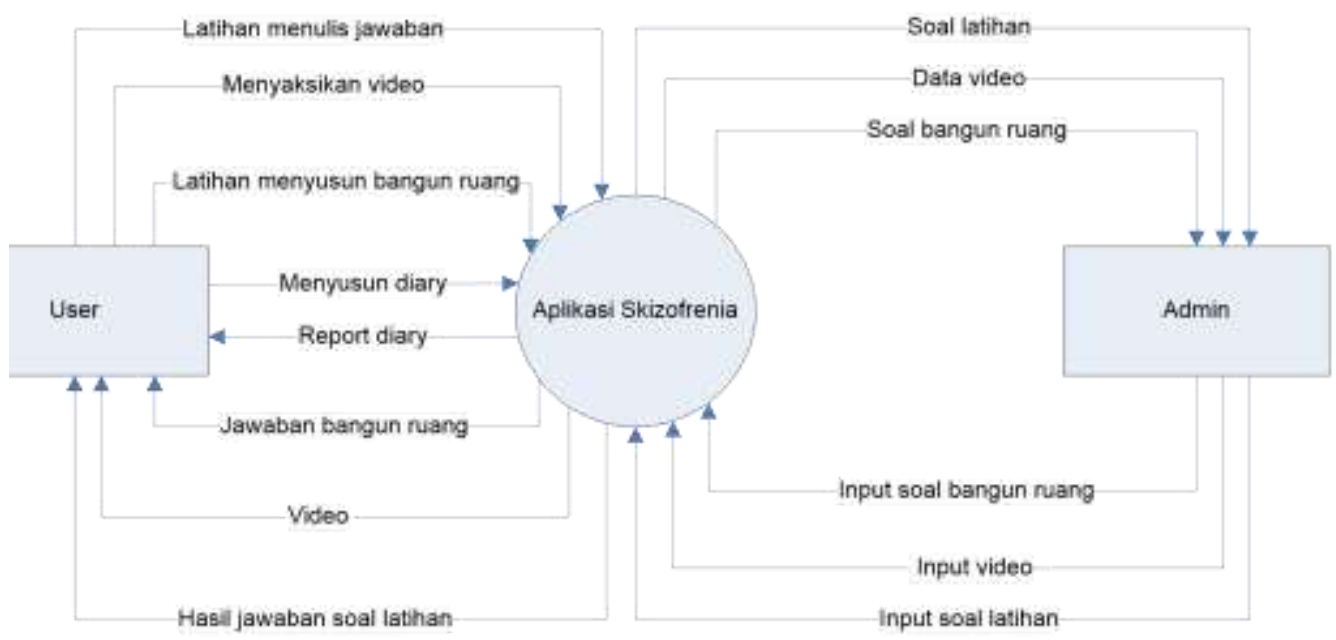

Gambar 2. Diagram Alir Data

Gambar 2 terdapat dua subjek yang dapat menggunakan aplikasi skizophrenia. Subjek pertama yakni admin yang dapat memasukkan soal latihan yang berupa soal paragraph pendek dan kalimat rumpang, data video, dan soal bangun ruang. Subjek kedua yakni user yang diposisikan sebagai perawat yang memandu penderita skizofrenia dalam menggunakan aplikasi skizofrenia.

\subsubsection{Flowchart Sistem}

Perancangan ini dilakukan untuk menampilkan proses dalam penggunaan aplikasi skizofrenia berbasis Android. Adapun bentuk flowchart dapat ditampilkan pada gambar 3 berikut.

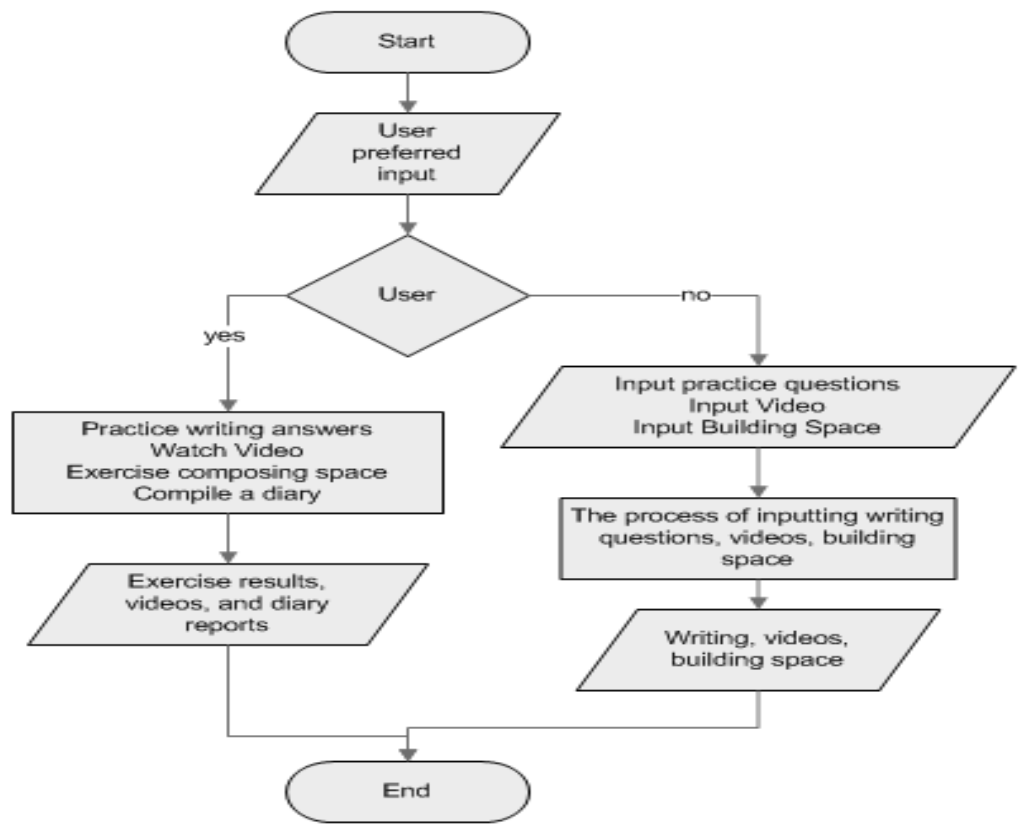

Gambar 3. Diagram Alir Sistem 


\section{Hasil dan Pembahasan \\ a. Penelitian Sebelumnya}

Penelitian sebelumnya yang berjudul Pola Bahasa Penderita Skizofrenia [10]. Penelitian tersebut meneliti tentang gangguan berbahasa penderita skizofrenia. Hasil penelitian tersebut yakni peneliti menemukan adanya kelainan pada kohesi dan koherensi pada penderita skizofrenia tingkat akut. Semakin tinggi keparahan penderita skizofrenia maka tingkat kerusakan kohesi dan koherensi semakin parah.

Penelitian tentang bahasa pada penderita skizofrenia bahwa penderita skizofrenia mengalami gangguan kognitif yang mana mereka tidak mampu mengartikan metafora [9]. Penelitian dengan judul Diary Skizofrenia Untuk Meningkatkan Kemampuan Penderita Skizofrenia Berbasis Android merupakan kelanjutan dari penelitian [10] sebelumnya.

\section{b. Hasil Tampilan Sistem}

Aplikasi skizophrenia diawali dengan membuka tampilan awal sebelum masuk ke dalam tampilan pendataan diary seperti pada gambar 4 berikut.

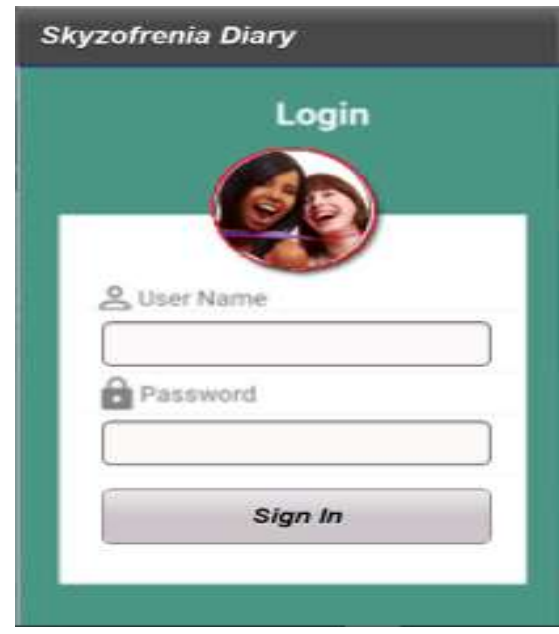

Gambar 4. Tampilan Login

Perawat akan menanyakan nama, usia, dan pekerjaan setiap penderita skizofrenia, kemudian menanyakan Kembali tentang kondisi penderita sebelum mencoba menggunakan aplikasi skizofrenia seperti ditampilkan pada gambar 5 .

Pada gambar 5, harus dilakukan pengisian data kondisi sebanyak 5 kali checklist. Apabila dapat terpenuhi pengisian kelima checklist tersebut maka dapat dilanjutkan pada Langkah penggunaan aplikasi selanjutnya.

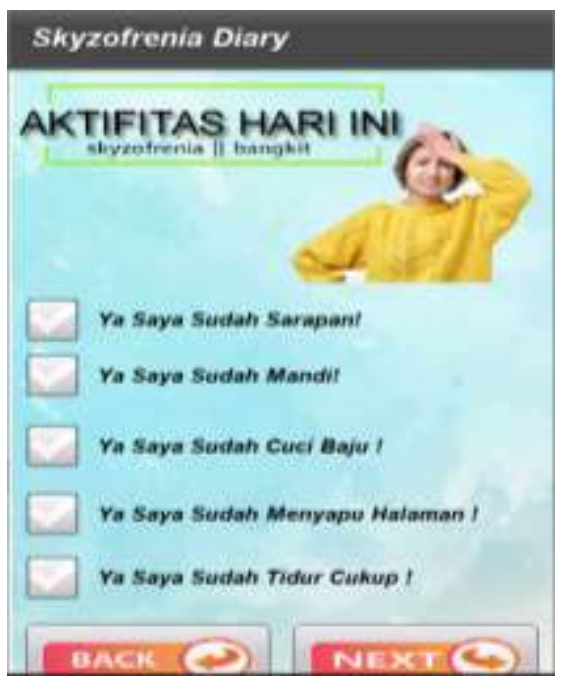

Gambar5. Tampilan Aktifitas 
Pada gambar 6 ditampilkan tampilan menu Skizophrenia Diary yang terdiri atas beberapa menu, diantaranya tes menulis, tes mendengarkan lagu, tes melihat video, tes Menyusun bangun ruang, dan test kalimat rumpang. Apabila seluruh tes selesai dilakukan, maka untuk melihat hasil nilai dapat diakses melalui menu hasil skor.

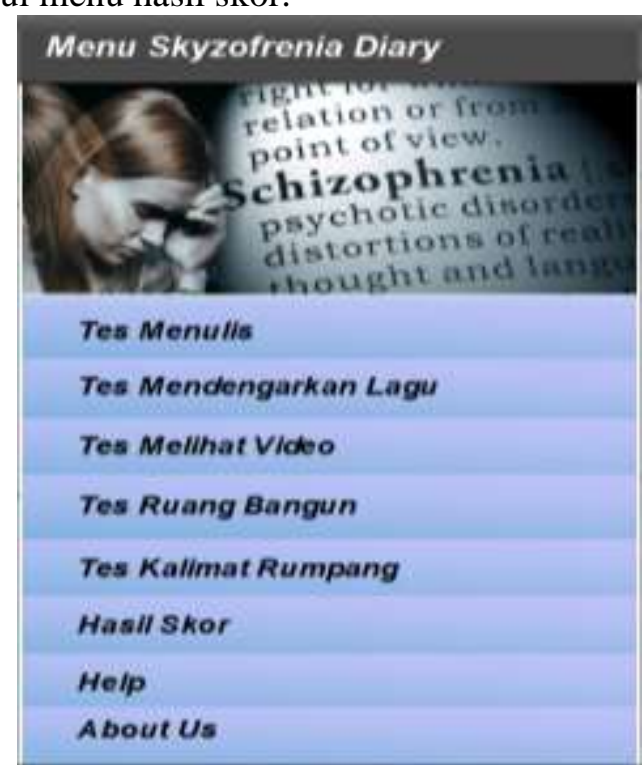

\section{Gambar 6.Menu Skizofreia Diary}

Setiap menu tes terdapat masing-masing 5 soal untuk dapat dijawab oleh penderita skizofrenia melalui panduan dari perawat. Nilai skor yang diberikan pada masing-masing soal yakni sebesar 4, sehingga total yang diperoleh untuk keseluruhan menu tes sebesar 100. Tampilan tes menulis yang merupakan menu tes yang diujikan kepada penderita skizofrenia misalnya pada tampilan tes menulis yang dapat ditampilkan pada gambar 7 .

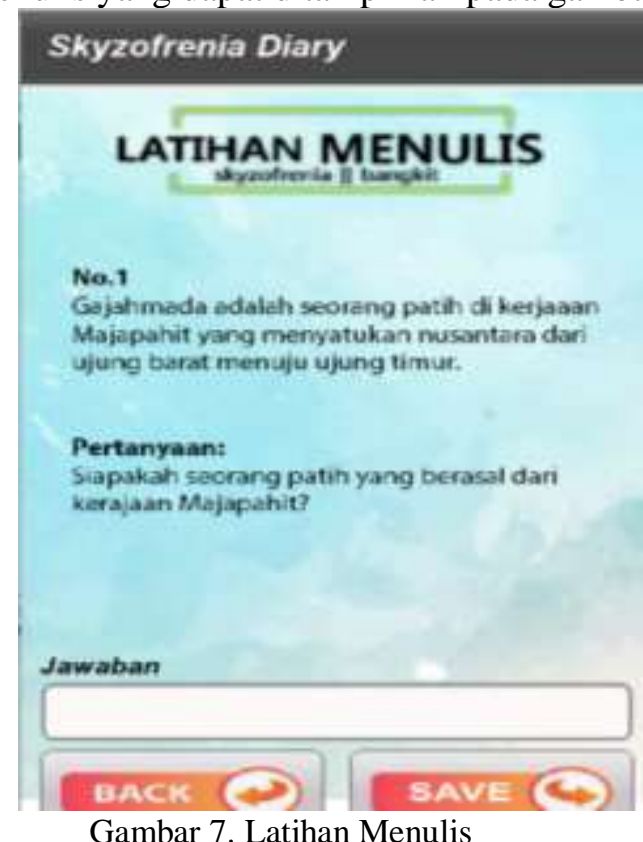

\section{b. Pengujian Sistem.}

1). Pengujian Alpha.

Aplikasi skizofrenia diary dilakukan dengan pengujian alpha dan beta. Pada pengujian alpha dilakukan dengan pengujian blackbox. Pada pengujian pertama dilakukan pada tampilan login sebanyak 3 kali pengujian seperti tabel 1 . 
Tabel 1. Pengujian Login

\begin{tabular}{ccccc}
\hline No & Deskripsi Pengujian & $\begin{array}{c}\text { Hasil yang } \\
\text { diperoleh }\end{array}$ & Hasil yang diharapkan & Kesimpulan \\
\hline 1 & $\begin{array}{c}\text { Memasukkan username } \\
\text { "user" dan password } \\
\text { "1122". }\end{array}$ & $\begin{array}{c}\text { Masuk ke tampilan } \\
\text { identitas }\end{array}$ & $\begin{array}{c}\text { Masuk ke tampilan } \\
\text { identitas }\end{array}$ & Valid \\
2 & $\begin{array}{c}\text { Memasukkan username } \\
\text { "User" dan password } \\
\text { "1122". }\end{array}$ & $\begin{array}{c}\text { Tidak masuk ke } \\
\text { tampilan identitas }\end{array}$ & $\begin{array}{c}\text { Masuk ke tampilan } \\
\text { identitas }\end{array}$ & Tidak Valid \\
& $\begin{array}{c}\text { Memasukkan username } \\
\text { "user" dan password } \\
\text { "1123". }\end{array}$ & $\begin{array}{c}\text { Tidak masuk ke } \\
\text { tampilan identitas }\end{array}$ & $\begin{array}{c}\text { Masuk ke tampilan } \\
\text { identitas }\end{array}$ & Tidak Valid \\
\hline
\end{tabular}
sebesar:

Berdasarkan kesimpulan kevalidan pengujian pada tabel 1 diperoleh prosentase validasi

$$
\begin{aligned}
& \text { prosentase validasi }=\frac{\text { Jumlah hasil valid }}{\text { Jumlah pengujian }} \times 100 \% \\
& \text { prosentase validasi }=\frac{1}{3} \times 100 \% \\
& \text { prosentase validasi }=33,33 \%
\end{aligned}
$$

Pada pengujian kedua dilakukan pada tampilan aktifitas hari ini sebanyak 3 kali pengujian yang dapat dilihat pada tabel 2 .

Tabel 2. Pengujian Aktifitas

\begin{tabular}{ccccc}
\hline No & Deskripsi Pengujian & $\begin{array}{c}\text { Hasil yang } \\
\text { diperoleh }\end{array}$ & $\begin{array}{c}\text { Hasil yang } \\
\text { diharapkan }\end{array}$ & Kesimpulan \\
\hline 1 & $\begin{array}{c}\text { Mengisikan semua } \\
\text { tanda centang pada } \\
\text { pilihan aktifitas. }\end{array}$ & $\begin{array}{c}\text { Masuk ke tampilan } \\
\text { tes skizofrenia diary }\end{array}$ & $\begin{array}{c}\text { Masuk ke tampilan tes } \\
\text { skizofrenia diary }\end{array}$ & Valid \\
2 & $\begin{array}{c}\text { Mengisikan salah satu } \\
\text { atau beberapa tanda } \\
\text { centang pada pilihan } \\
\text { aktifitas. }\end{array}$ & $\begin{array}{c}\text { Tidak masuk ke } \\
\text { tampilan tes } \\
\text { skizofrenia diary }\end{array}$ & $\begin{array}{c}\text { Masuk ke tampilan tes } \\
\text { skizofrenia diary }\end{array}$ & Tidak Valid \\
& $\begin{array}{c}\text { Tidak mengisikan } \\
\text { tanda centang pada } \\
\text { pilihan aktifitas. }\end{array}$ & $\begin{array}{c}\text { Tidak masuk ke } \\
\text { tampilan tes } \\
\text { skizofrenia diary }\end{array}$ & $\begin{array}{c}\text { Tidak masuk ke } \\
\text { tampilan tes } \\
\text { skizofrenia diary }\end{array}$ & Valid \\
\hline
\end{tabular}

Berdasarkan kesimpulan kevalidan pengujian pada tabel 2 diperoleh prosentase validasi sebesar:

$$
\begin{gathered}
\text { prosentase validasi }=\frac{2}{3} \times 100 \% \\
\text { prosentase validasi }=66,67 \%
\end{gathered}
$$

\begin{tabular}{|c|c|c|c|c|}
\hline No & Deskripsi Pengujian & $\begin{array}{l}\text { Hasil yang } \\
\text { diperoleh }\end{array}$ & $\begin{array}{l}\text { Hasil yang } \\
\text { diharapkan }\end{array}$ & Kesimpulan \\
\hline 1 & $\begin{array}{l}\text { Mengisikan } 5 \text { jawaban } \\
\text { dengan benar/ salah. }\end{array}$ & $\begin{array}{l}\text { Jawaban tersimpan } \\
\text { dan kembali ke } \\
\text { tampilan tes } \\
\text { skizofrenia diary }\end{array}$ & $\begin{array}{l}\text { Jawaban tersimpan } \\
\text { dan kembali ke } \\
\text { tampilan tes } \\
\text { skizofrenia diary }\end{array}$ & Valid \\
\hline 2 & $\begin{array}{c}\text { Tidak mengisikan } 5 \\
\text { jawaban. }\end{array}$ & $\begin{array}{l}\text { Kembali ke tampilan } \\
\text { tes skizofrenia diary }\end{array}$ & $\begin{array}{l}\text { Kembali ke tampilan } \\
\text { tes skizofrenia diary }\end{array}$ & Valid \\
\hline
\end{tabular}

Pada pengujian ketiga dilakukan pada tampilan tes menulis sebanyak 2 kali pengujian yang dapat dilihat pada tabel 3 .

Tabel 3. Pengujian Tes Menulis 

sebesar:

Berdasarkan kesimpulan kevalidan pengujian pada tabel 3 diperoleh prosentase validasi

$$
\begin{gathered}
\text { prosentase validasi }=\frac{2}{2} \times 100 \% \\
\text { prosentase validasi }=100 \%
\end{gathered}
$$

Pada pengujian keempat dilakukan pada tampilan tes mendengarkan lagu sebanyak 6 kali pengujian yang dapat dilihat pada tabel 4 .

\begin{tabular}{|c|c|c|c|c|}
\hline No & Deskripsi Pengujian & $\begin{array}{l}\text { Hasil yang } \\
\text { diperoleh }\end{array}$ & $\begin{array}{l}\text { Hasil yang } \\
\text { diharapkan }\end{array}$ & Kesimpulan \\
\hline 1 & $\begin{array}{l}\text { Menekan tombol } \\
\text { "Putar Lagu" }\end{array}$ & $\begin{array}{l}\text { Lagu berhasil } \\
\text { didengarkan }\end{array}$ & $\begin{array}{l}\text { Lagu berhasil } \\
\text { didengarkan }\end{array}$ & Valid \\
\hline 2 & $\begin{array}{l}\text { Menekan tombol } \\
\text { "Stop" }\end{array}$ & $\begin{array}{l}\text { Lagu berhasil } \\
\text { dihentikan }\end{array}$ & $\begin{array}{l}\text { Lagu berhasil } \\
\text { dihentikan }\end{array}$ & Valid \\
\hline 3 & $\begin{array}{l}\text { Mengisikan } 5 \text { jawaban } \\
\text { dengan benar/ salah } \\
\text { dengan menekan } \\
\text { tombol "Stop" } \\
\text { sebelumnya. }\end{array}$ & $\begin{array}{l}\text { Jawaban tersimpan } \\
\text { dan kembali ke } \\
\text { tampilan tes } \\
\text { skizofrenia diary }\end{array}$ & $\begin{array}{c}\text { Jawaban tersimpan } \\
\text { dan kembali ke } \\
\text { tampilan tes } \\
\text { skizofrenia diary }\end{array}$ & Valid \\
\hline 4 & $\begin{array}{l}\text { Tidak mengisikan } 5 \\
\text { jawaban dengan } \\
\text { menekan tombol } \\
\text { "Stop" sebelumnya. }\end{array}$ & $\begin{array}{l}\text { Kembali ke tampilan } \\
\text { tes skizofrenia diary }\end{array}$ & $\begin{array}{l}\text { Kembali ke tampilan } \\
\text { tes skizofrenia diary }\end{array}$ & Valid \\
\hline 5 & $\begin{array}{l}\text { Mengisikan } 5 \text { jawaban } \\
\text { dengan benar/ salah } \\
\text { tanpa menekan tombol } \\
\text { "Stop" sebelumnya. }\end{array}$ & $\begin{array}{c}\text { Jawaban tersimpan } \\
\text { dan kembali ke } \\
\text { tampilan tes } \\
\text { skizofrenia diary, } \\
\text { tetapi lagu tidak } \\
\text { berhenti diputar. }\end{array}$ & $\begin{array}{c}\text { Jawaban tersimpan } \\
\text { dan kembali ke } \\
\text { tampilan tes } \\
\text { skizofrenia diary }\end{array}$ & Tidak Valid \\
\hline 6 & $\begin{array}{l}\text { Tidak mengisikan } 5 \\
\text { jawaban tanpa } \\
\text { menekan tombol } \\
\text { "Stop" sebelumnya. }\end{array}$ & $\begin{array}{l}\text { Kembali ke tampilan } \\
\text { tes skizofrenia diary, } \\
\text { tetapi lagu tidak } \\
\text { berhenti diputar. }\end{array}$ & $\begin{array}{l}\text { Kembali ke tampilan } \\
\text { tes skizofrenia diary }\end{array}$ & Tidak Valid \\
\hline
\end{tabular}

Tabel 4. Pengujian Tes Mendengarkan Lagu sebesar:

Berdasarkan kesimpulan kevalidan pengujian pada tabel 4 diperoleh prosentase validasi

$$
\begin{gathered}
\text { prosentase validasi }=\frac{4}{6} \times 100 \% \\
\text { prosentase validasi }=66,67 \%
\end{gathered}
$$

\begin{tabular}{|c|c|c|c|c|}
\hline No & Deskripsi Pengujian & $\begin{array}{l}\text { Hasil yang } \\
\text { diperoleh }\end{array}$ & $\begin{array}{l}\text { Hasil yang } \\
\text { diharapkan }\end{array}$ & Kesimpulan \\
\hline 1 & $\begin{array}{c}\text { Menekan tombol "Putar } \\
\text { Video" }\end{array}$ & $\begin{array}{l}\text { Video berhasil } \\
\text { diputar }\end{array}$ & Video berhasil diputar & Valid \\
\hline 2 & Menekan tombol "Stop" & $\begin{array}{l}\text { Video berhasil } \\
\text { dihentikan }\end{array}$ & $\begin{array}{l}\text { Video berhasil } \\
\text { dihentikan }\end{array}$ & Valid \\
\hline 3 & $\begin{array}{l}\text { Mengisikan } 5 \text { jawaban } \\
\text { dengan benar/ salah } \\
\text { dengan menekan tombol } \\
\text { "Stop" sebelumnya. }\end{array}$ & $\begin{array}{c}\text { Jawaban tersimpan } \\
\text { dan kembali ke } \\
\text { tampilan tes } \\
\text { skizofrenia diary }\end{array}$ & $\begin{array}{c}\text { Jawaban tersimpan } \\
\text { dan kembali ke } \\
\text { tampilan tes } \\
\text { skizofrenia diary }\end{array}$ & Valid \\
\hline
\end{tabular}

Pada pengujian kelima dilakukan pada tampilan tes melihat video sebanyak 6 kali pengujian yang dapat dilihat pada tabel 5 .

Tabel 5. Pengujian Tes Mendengarkan Lagu 


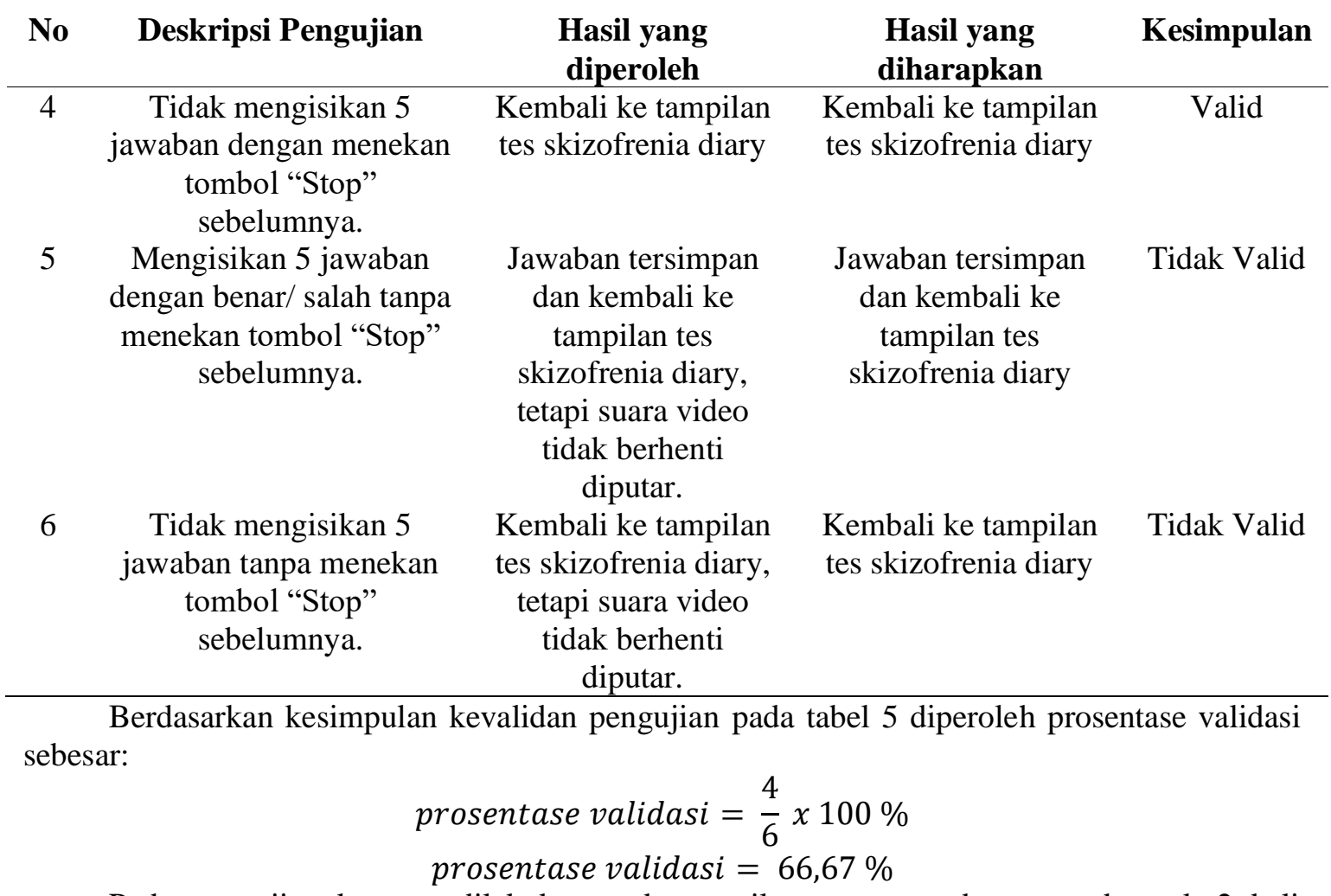

Pada pengujian keenam dilakukan pada tampilan tes ruang bangun sebanyak 2 kali pengujian yang dapat dilihat pada tabel 6 .

Tabel 6. Pengujian Tes Ruang Bangun

\begin{tabular}{|c|c|c|c|c|}
\hline No & Deskripsi Pengujian & $\begin{array}{l}\text { Hasil yang } \\
\text { diperoleh }\end{array}$ & $\begin{array}{l}\text { Hasil yang } \\
\text { diharapkan }\end{array}$ & Kesimpulan \\
\hline 1 & $\begin{array}{l}\text { Mengisikan } 5 \text { jawaban } \\
\text { dengan benar/ salah. }\end{array}$ & $\begin{array}{c}\text { Jawaban tersimpan } \\
\text { dan kembali ke } \\
\text { tampilan tes } \\
\text { skizofrenia diary }\end{array}$ & $\begin{array}{c}\text { Jawaban tersimpan } \\
\text { dan kembali ke } \\
\text { tampilan tes } \\
\text { skizofrenia diary }\end{array}$ & Valid \\
\hline 2 & $\begin{array}{c}\text { Tidak mengisikan } 5 \\
\text { jawaban. }\end{array}$ & $\begin{array}{l}\text { Kembali ke tampilan } \\
\text { tes skizofrenia diary }\end{array}$ & $\begin{array}{l}\text { Kembali ke tampilan } \\
\text { tes skizofrenia diary }\end{array}$ & Valid \\
\hline
\end{tabular}
sebesar:

$$
\begin{gathered}
\text { prosentase validasi }=\frac{2}{2} \times 100 \% \\
\text { prosentase validasi }=100 \%
\end{gathered}
$$

Pada pengujian ketujuh dilakukan pada tampilan tes kalimat rumpang sebanyak 2 kali pengujian yang dapat dilihat pada tabel 7 .

Tabel 7. Pengujian Tes Kalimat Rumpang

\begin{tabular}{ccccc}
\hline No & Deskripsi Pengujian & $\begin{array}{c}\text { Hasil yang } \\
\text { diperoleh }\end{array}$ & $\begin{array}{c}\text { Hasil yang } \\
\text { diharapkan }\end{array}$ & Kesimpulan \\
\hline 1 & $\begin{array}{c}\text { Mengisikan 5 jawaban } \\
\text { dengan benar/ salah. }\end{array}$ & $\begin{array}{c}\text { Jawaban tersimpan } \\
\text { dan kembali ke } \\
\text { tampilan tes } \\
\text { skizofrenia diary } \\
\text { Kembali ke tampilan } \\
\text { tes skizofrenia diary }\end{array}$ & $\begin{array}{c}\text { Jan kembali ke } \\
\text { tampilan tes } \\
\text { skizofrenia diary } \\
\text { Kembali ke tampilan } \\
\text { tes skizofrenia diary }\end{array}$ & Valid \\
& $\begin{array}{c}\text { Tidak mengisikan 5 } \\
\text { jawaban. }\end{array}$ & $\begin{array}{c}\text { Valid } \\
\text { tempan }\end{array}$ & \\
\hline
\end{tabular}



sebesar:

Berdasarkan kesimpulan kevalidan pengujian pada tabel 7 diperoleh prosentase validasi

$$
\begin{gathered}
\text { prosentase validasi }=\frac{2}{2} \times 100 \% \\
\text { prosentase validasi }=100 \%
\end{gathered}
$$

Setelah dilakukan tujuh pengujian dengan menggunakan Blackbox testing, maka diperoleh tingkat rata-rata prosentase kevalidan sebesar:

$$
\text { rerata prosentase validas } i=\frac{\text { Jumlah hasil prosentase valid }}{\text { Jumlah total pengujian }}
$$

rerata prosentase validasi $=\frac{33,33 \%+66,67 \%+100 \%+66,67 \%+66,67 \%+100 \%+100 \%}{7}$

\section{2). Pengujian Beta.}

$$
\text { rerata prosentase validasi }=76,19 \%
$$

Pada pengujian beta dilakukan terhadap 2 penguji, diantaranya oleh penguji ahli materi dan penguji ahli media.

Pengujian aplikasi skizofrenia oleh penguji ahli materi dilakukan oleh dr Azimatul

\begin{tabular}{|c|c|c|c|c|c|c|}
\hline \multirow{2}{*}{ Nomor } & \multirow{2}{*}{ Keterangan } & \multicolumn{5}{|c|}{ Penilaian Ahli Materi } \\
\hline & & 1 & 2 & 3 & 4 & 5 \\
\hline 1. & Huruf dapat terlihat dengan baik & & & & & $\mathrm{v}$ \\
\hline 2. & $\begin{array}{c}\text { Suara dapat terdengar dengan } \\
\text { baik }\end{array}$ & & & & & $v$ \\
\hline 3. & $\begin{array}{l}\text { Tampilan soal bangun ruang } \\
\text { Item yang terdapat dalam }\end{array}$ & & & & & $v$ \\
\hline 4. & $\begin{array}{l}\text { aplikasi cocok diterapkan untuk } \\
\text { memperbaiki kognisi penderita } \\
\text { skizofrenia }\end{array}$ & & & & $v$ & \\
\hline 5. & Ukuran dan jenis huruf & & & & v & \\
\hline 6. & Warna dan gambar & & & & $\mathrm{v}$ & \\
\hline 7. & Video & & & & $v$ & \\
\hline 8. & Gambar & & & $\mathrm{v}$ & & \\
\hline 9. & Penyajian materi & & & & & $\mathrm{v}$ \\
\hline 10. & Kejelasan Petunjuk & & & & $v$ & \\
\hline 11. & Kemudahan Penggunaan Media & & & & & v \\
\hline & Jumlah Frekuensi & 0 & 0 & 1 & 5 & 5 \\
\hline & Jumlah Skor & 0 & 0 & 1 & 5 & 5 \\
\hline & Rata-rata & 0 & 0 & 0,09 & 45,45 & 45,45 \\
\hline & Presentase & 0 & 0 & $9,09 \%$ & $45,45 \%$ & $45,45 \%$ \\
\hline
\end{tabular}
Karimah, SPKj. Dari rumah sakit Menur Surabayadengan menunjukkan aplikasi terlebih dulu kemudian diuji hasilnya melalui angket penilaian aplikasi oleh ahil materi seperti pada tabel 8 .

\section{Tabel 8. Angket penilaian aplikasi oleh Ahli Materi}

Pada tabel 8 terdapat lima skala likert; diantaranya $1=$ Sangat tidak menarik, $2=$ tidak menarik, 3 = biasa saja; 4 = Menarik, dan 5 = Sangat Menarik.

Pengujian aplikasi skizofrenia oleh penguji ahli media dilakukan oleh Dosen Teknik Informatika ITS Surabaya Hudan Studiawan, ST,MT dengan menunjukkan aplikasi terlebih dulu kemudian diuji hasilnya melalui angket penilaian aplikasi oleh ahil media seperti pada tabel 9.

Tabel 9. Angket penilaian aplikasi oleh Ahli Media

Nomor Keterangan Penilaian Ahli Media




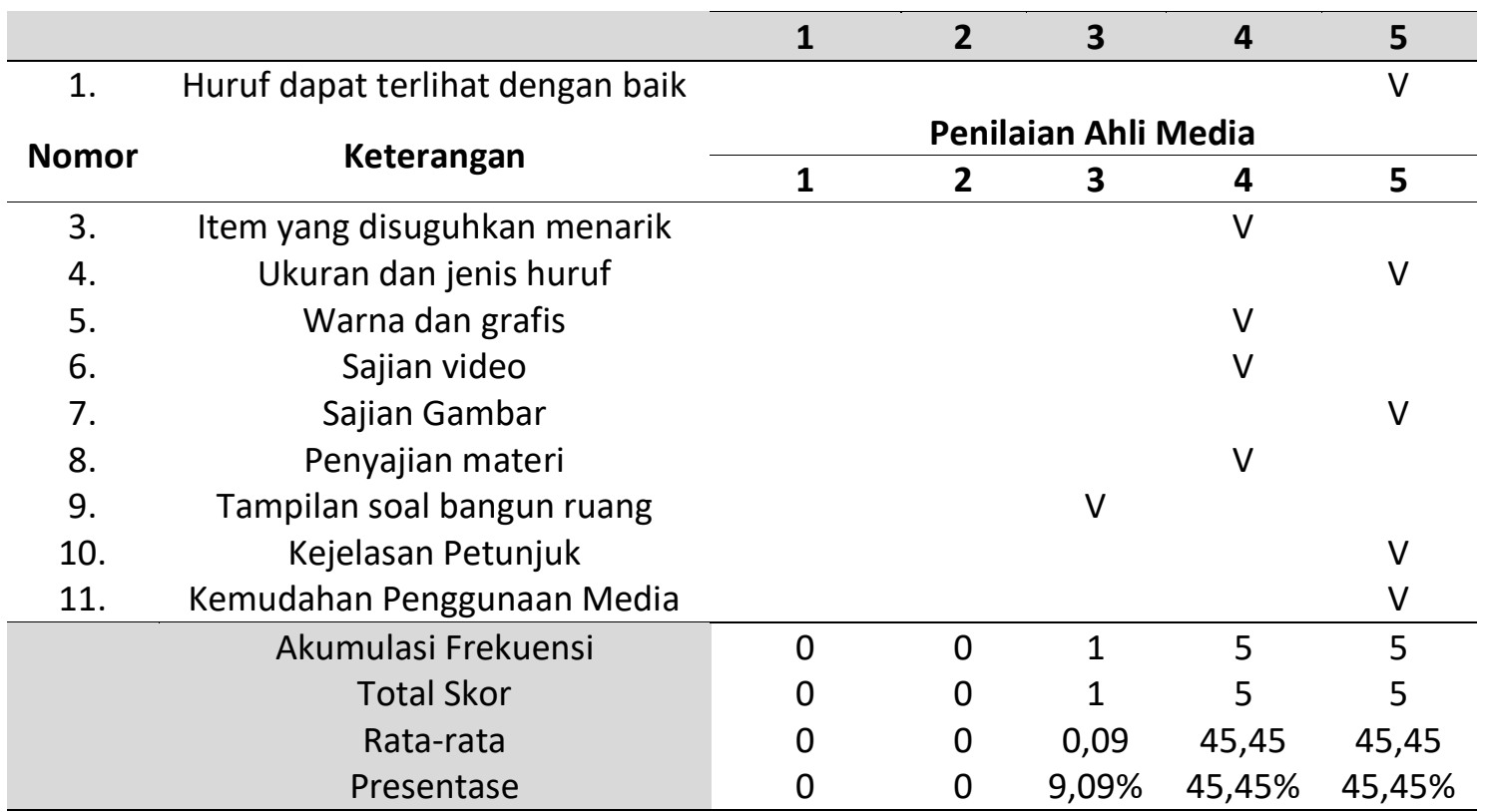

Berdasarkan tabel 8 dan 9, maka diperoleh hasil penilaian yang sama pada setiap skala likert diantaranya penilaian aplikasi sangat menarik sebesar $45,45 \%$; aplikasi menarik sebesar $45,45 \%$, dan aplikasi biasa saja sebesar 9,09\%.

\section{c. Hasil Penerapan Aplikasi terhadap Kemampuan Kognitif Penderita Skizofrenia}

Aplikasi yang dibuat oleh peneliti yaitu Schizophrenics Diary for improving Language Skills berbanding lurus dengan skala Scors yang diterapkan. Semakin kecil nilai Scors nya maka tingkat keparahan semakin tinggi. Penderita skizofrenia yang memiliki skala Scors rendah maka mereka juga tidak mampu mengerjakan soal pada aplikasi. Dengan kata lain, kemampuan kognitifnya rendah. Mereka yang memiliki Scors yang tinggi dapat dikatakan mempunyai kognitif yang relative bagus maka skor dalam pemakaian aplikasi cenderung tinggi. Perhatikan table

Tabel 10. Perbandingan Skor Skala Penilaian Kognitif Skizofrenia ( SCORS) dan Skor Pemakaian Aplikasi

\begin{tabular}{cccccc}
\hline No & Nama & Usia & Pekerjaan & Skor Scors & $\begin{array}{c}\text { Skor } \\
\text { Aplikasi }\end{array}$ \\
\hline 1 & Ht & 46 & IRT & 198 & 55 \\
2 & HR & 43 & IRT & 182 & 35 \\
3 & SJ & 36 & - & 197 & 60 \\
4 & Bdn & 28 & Petani & 183 & 70 \\
5 & mulj & 47 & Petani & 160 & 10 \\
6 & Sul & 49 & Petani & 167 & 0 \\
7 & Ed & 45 & - & 161 & 10 \\
8 & Rah & 37 & - & 162 & 0 \\
9. & Stn & 40 & - & 160 & 0 \\
10 & Sp & 40 & - & 170 & 10 \\
\hline
\end{tabular}

\section{Kesimpulan}

Penderita Skizofrenia pada tahap keparahan yang tinggi mengalami hendaya kognitif social atau penurunan kognitif social yang cenderung parah. Maka dari itu perlu adanya treatment atau latihan untuk meningkatkan kemampuan kognitif mereka.

Schizophrenic Diary merupakan suatu aplikasi untuk meningkatkan kemampuan kognitif penderita skizofrenia. Semakin tinggi skala SCORS maka semakin tinggi pula nilai pengerjaan aplikasi Schizophrenic's Diary.Untuk penggunaan secara berkala bisa digunakan sebagai terapi untuk pendamping obat. Sehingga semakin lama kemampuan kogitif enderita skiofrenia 
semakin meningkat. Alpha testing yang dilakukan melalui pengujian Black Box dapat diperoleh tingkat akurasi pengujian sebesar $79,19 \%$, sedangkan untuk Beta testing yang dilakukan terhadap ahli media dan dokter psikiater diperoleh tingkat akurasi pengujian masing-masing sebesar $45,45 \%$.

\section{Daftar Pustaka}

[1] Kristanti. R, Azimatul. K, Atikah, and Aryati, "Hubungan Antara kadar Vitamin D Serum dan Defisit Kognitif pada Pasien Skizofrenia", 6. Departement Ilmu Kedokteran Jiwa RSUD Dr. Soetomo. 2019.

[2] Hidayati, R. T, "Pengaruh Terapi Kognitif Dan Perilaku Terhadap Peningkatan Kemampuan Perawatan Diri Pada Klien Skizofrenia Dengan Defisit Perawatan Diri Di Rsjd Dr. Amino Gondohutomo", Surabaya: Universitas Airlangga, 2018.

[3] Siahaan, E. S, "Persepsi Pasien Skizofrenia Tentang Perawatan Diri di Rumah Sakit Jiwa Prof dr M Ildrem Medan", Medan: Universitas Sumatera Utara, 2018.

[4] Lysaker, "Metacognitive function and fragmentation in schizophrenia: Relationship to cognition, self-experience and developing treatments", Elsevier, pp.1. 2020.

[5] Rene. R. S, Irris. S.E, Murray. M, Andreas. L.M, Daniel. W. R, Tyron. C.D, Michael. O, Christopher, C.U, John, K.M, Jim, O.V, Thomas, I.R, "Schizophrenia”, Primer, pp.1, 2015.

[6] Katherine, B. E, Mercedes, R. P, Rebecca, B, Megan, S, Emmet, L, Cierra, H, Jessica, $\mathrm{P}$, Pamela, S, "A molecular approach to treating cognition in schizophrenia by calcium channel blockade An open-label pilot study of the calcium-channel antagonist isradipine", Elsivier, pp.1, 2020.

[7] Mørkveda. M, Johnsen. E, Krokenc. R. A, Gjestadc. R, Winjef. D, Thimmb. J, Fathiang. F, Rettenbacherk. M, Andai. L.G, Løbergc. E.M, "Does childhood trauma influence cognitive functioning in schizophrenia?", Elsevier, pp.1, 2020.

[8] Pandinaa. G, Nuamaha. I, Petersenb. T, Singha. J, Savitza. A, Hougha. D, “Cognitive functioning in adolescents with schizophrenia treated with paliperidone extendedrelease: 6-Month exploratory analysis from an openlabel, single-arm safety study", Elsevier, pp.1. 2020.

[9] Felicity. F, Ellen. P, Quoc. V. C, Nicol. F, Andreas. F, Wolfram. H, "Watsond Stuart Non-literal understanding and psychosis: Metaphor comprehension in individuals with a diagnosis of schizophrenia", Elsivier, pp.1, 2020.

[10] Rahmatika. A. P, "Pola Bahasa pada Penderita Skizofrenia", Yogyakarta: Universitas Gadjahmada, 2015.

[11] Zanelli, "Cognitive Change in Schizophrenia and Other Psychoses in the Decade Following the First Episode Am J Psychatri", pp.1. 2017.

[12] Rini, Susilo. W, Hadjan, Rahman. N, "Efktifitas Remediasi Kognitif terhadap Perbaikan Fungi Kognitif pada Penderita Skizofrenia Rawat Inap di Rumah Sakit Jiwa A di Yogyakarta”, Vol.2, No.2, Gadjah Mada Journal of Proffesional Psychology, 2016.

[13] Damanika, Pardede, Manalu, "Terapi Kognitif Terhadap Kemampuan Interaksi Pasien Skizofrenia dengan Isolasi Sosial.Jurnal Kebidanan dan Keperawatan”, pp.228, 2020.

[14] Miley, "Six month durability of targeted cognitive training supplemented with social cognition exercises in schizophrenial", Elsevier, pp.1, 2020.

[15] Andi. R, Sysnawati, "Mengontrol Pikiran Negatif Klien Schizophrenia dengan Terapi Kognitif", Journal Of Islamic Nursing. pp.48. 2018.

\section{(i) (2)}

Digital Zone: Jurnal Teknologi Informasi dan Komunikasi is licensed under a Creative Commons Attribution International (CC BY-SA 4.0) 